\title{
Effects of fire on soil nitrogen dynamics and microbial biomass in savannas of Central Brazil(1)
}

\author{
Gabriela Bielefeld Nardoto(2) and Mercedes Maria da Cunha Bustamante ${ }^{(3)}$
}

\begin{abstract}
The objective of this work was to study the effects of fire on net $\mathrm{N}$ mineralization and soil microbial biomass in burned and unburned cerrado stricto sensu sites. The study was carried out from April 1998 to April 2000. The $\mathrm{pH}$ values were significantly higher in the burned site while soil moisture content was significantly higher in the unburned site $(\mathrm{P}<0.05)$. The soil $\mathrm{C} / \mathrm{N}$ ratio was $22 / 1$ and the available $\mathrm{NO}_{3}-\mathrm{N}$ ranged between 1.5 and $2.8 \mathrm{mg} \mathrm{kg}^{-1}$ dry weight. However, the $\mathrm{NH}_{4}-\mathrm{N}$ concentration ranged between 3 and $34 \mathrm{mg} \mathrm{kg}^{-1}$ dry weight in the burned site and between 3 and $22 \mathrm{mg} \mathrm{kg}^{-1} \mathrm{dry}$ weight in the unburned site. The $\mathrm{NH}_{4}-\mathrm{N}$ increased after fire, but no significant changes were observed for $\mathrm{NO}_{3}-\mathrm{N}(\mathrm{P}<0.05)$. The $\mathrm{NO}_{3}-\mathrm{N}$ accumulation occurred in short periods during the rainy season. The rates of net $\mathrm{N}$ mineralization increased during the rainy season while reductions in soil microbial biomass were observed at both sites. This suggested that the peak in microbial activities occurred with the first rain events, with an initial net immobilization followed by net mineralization. Both sites presented the same pattern for mineralization/immobilization, however, the amount of inorganic- $\mathrm{N}$ cycled annually in unburned site was $14.7 \mathrm{~kg} \mathrm{ha}^{-1}$ per year while the burned site presented only $3.8 \mathrm{~kg} \mathrm{ha}^{-1}$ of inorganic-N, one year after the burning.
\end{abstract}

Index terms: nitrogen mineralization, nitrification, inorganic compounds, burning.

\section{Efeitos do fogo na dinâmica do nitrogênio no solo e biomassa microbiana em área de Cerrado}

Resumo - O objetivo deste trabalho foi estudar o efeito do fogo sobre as taxas de mineralização líquida de $\mathrm{N}$ e biomassa microbiana do solo em áreas de cerrado stricto sensu. $\mathrm{O}$ estudo foi realizado entre abril de 1998 e abril de 2000 . O pH foi maior na área queimada enquanto o teor de umidade do solo foi maior na área sem queima $(\mathrm{P}<0,05)$. A razão $\mathrm{C} / \mathrm{N}$ do solo foi de $22 / 1$. A concentração de $\mathrm{N}$ nítrico disponível ficou entre 1,5 e $2,8 \mathrm{mg} \mathrm{kg}^{-1}$ de matéria seca enquanto a de $\mathrm{N}$ amoniacal variou entre $3 \mathrm{e}$ $34 \mathrm{mg} \mathrm{kg}^{-1}$ de matéria seca na área queimada e entre 3 e $22 \mathrm{mg} \mathrm{kg}^{-1}$ de matéria seca na área sem queima. A concentração de $\mathrm{N}$ amoniacal aumentou significativamente após o fogo $(\mathrm{P}<0,05)$. Pequenos acúmulos de $\mathrm{N}$ nítrico no solo ocorreram somente durante curto período na estação chuvosa. A biomassa microbiana teve seu pico máximo em novembro de 1998 , chegando a $850 \mathrm{mg} \mathrm{kg}^{-1} \mathrm{de} \mathrm{C}$ no solo da área queimada. Os dados indicam que o pico da atividade microbiana ocorreu no início das chuvas, com um período inicial de imobilização seguido de mineralização líquida. Ambas as áreas apresentaram um mesmo padrão de mineralização/imobilização, mas com menor produção anual de $\mathrm{N}$ mineral na área queimada (14,7 $\mathrm{kg} \mathrm{ha}^{-1}$ por ano na área sem queima e $3,8 \mathrm{~kg} \mathrm{ha}^{-1}$ por ano na área queimada), um ano após a queima.

Termos para indexação: mineralização do nitrogênio, nitrificação, composto inorgânico, queimada.

\footnotetext{
(1) Accepted for publication on April 2, 2003.

${ }^{(2)}$ Universidade de São Paulo, Centro de Energia Nuclear na Agricultura, Caixa Postal 96, CEP 13400-970 Piracicaba, SP. E-mail: gbnardot@carpa.ciagri.usp.br

${ }^{(3)}$ Universidade de Brasília, Dep. de Ecologia, Campus Darcy Ribeiro, Asa Norte, CEP 70919-970 Brasília, DF, Brasil. E-mail: mercedes@unb.br
}

\section{Introduction}

Biomass burning in the tropics affects atmospheric chemistry and biogeochemical cycles of tropical ecosystems (Crutzen \& Andreae, 1990). The $\mathrm{N}$ cycle is particularly sensitive to changes induced by frequent fires due to substantial loss of this ele- 
ment through volatilization. Because tropical savannas cover an area of about 1,900 million ha and are burned every one to four years during the dry season, with the highest frequency in the humid savannas, they are particularly important to regional and global atmospheric chemistry.

The Cerrado vegetation is considered a wet seasonal savanna that occurs mostly in Central Brazil and covers more than $20 \%$ of the Brazilian territory. It is characterized by a very variable structure, ranging from open grasslands (campo limpo), through open scrubland (campo sujo and cerrado sensu stricto) to dense woodlands (cerradão) (Eiten, 1994).

In the Cerrado, fires set by man and lightning are common in the dry season and have been occurring for thousands of years (Salgado-Labouriau \& Vicentini, 1994). Fire is a factor of recognized ecological importance influencing the nutrient cycling and affecting the dynamics of the vegetation, particularly the grass/woody biomass ratio. Sato et al. (1998), studying the impact of prescribed fires in Cerrado areas, reported a reduction of $26.8 \%$ and $37.8 \%$ of the woody vegetation after three cycles of prescribed fires (every two years), respectively, in the middle and at the end of the dry season. The high mortality rates suggest that the fire regime used changed the physiognomy of the vegetation to a more open form, with the grasses as the major component of the herbaceous layer and favoring the occurrence of more intense fires (Miranda et al., 1996).

Direct transformation of elements during fire combustion can affect the cycling and availability of nutrients during many years following the disturbance. The combustion of organic matter releases significant quantities of available nutrients and can be an important source for plant regrowth. The mineral ash can also influence the soil $\mathrm{pH}$ and microbial activities related to decomposition and nutrient turnover (Kauffman et al., 1992). The soil microbial biomass acts as an important ecological indicator and is responsible for the decomposition and mineralization of plant and animal residues in the soil. The microbial biomass may be a main source of nutrient for plants and may contribute to nutrient conservation (Singh et al., 1989).

Nitrogen mineralization and nitrification have been studied in various ecosystems (Adams \&
Attiwill, 1986; Vitousek \& Matson, 1988; Davidson et al., 1992). In many of them, net $\mathrm{N}$ mineralization increases during the first months after a prescribed fire. This short duration of the fire effect is followed by a period in which the rate of net mineralization returns to prefire levels, and, in many cases, turns to net $\mathrm{N}$ immobilization six months to two years after the fire event (Adams \& Attiwill, 1986; Knoepp \& Swank, 1995).

The effects of burning on soil chemistry, gross $\mathrm{N}$ mineralization and emissions of $\mathrm{N}$ trace gases have been reported in short-term experiments in Cerrado areas (Poth et al., 1995; Verchot et al., 1999). However, little is known about the consequences of fire and seasonal variation for the control of soil $\mathrm{N}$ biogeochemistry in the Cerrado.

The objective of this work was to study the effects of fire on net $\mathrm{N}$ mineralization and soil microbial biomass in burned and unburned cerrado stricto sensu areas.

\section{Material and Methods}

The study was carried out at the Reserva Ecológica do IBGE (35 km south from Brasília, DF, 1555' S and $\left.47^{\circ} 52^{\prime} \mathrm{W}\right)$. This reserve is the only area of Cerrado that has a well known fire history and since 1990 a large experiment on the effects of prescribed burnings has been conducted. The climate is Aw (Köppen classification), with a mean annual precipitation between 1,100 and 1,600 mm, $90 \%$ of which falls in the rainy season (October to April). The studied sites (plots of $200 \mathrm{~m}$ x $500 \mathrm{~m}$ ) are typical cerrado stricto sensu areas and are separated by a distance of $1.5 \mathrm{~km}$. Cerrado stricto sensu occupies around 53\% of the Cerrado region and is composed by a continuous ground layer dominated by grasses and a woody layer of trees and shrubs varying in ground cover from $10 \%$ to 60\% (Eiten, 1994). The soil has been classified as Oxisols (Dystrophic Red Latosols in the Brazilian classification that covers around $20 \%$ of Cerrado soils) with acidic $\mathrm{pH}$ values, high aluminum saturation and low cation exchange capacity. The unburned site has been protected against fire since 1974 and the burned site has been subjected to prescribed fires every two years at the end of the dry season (September), since 1992.

Soil samples were taken before and after the fourth prescribed fire (September 1998). Three soil samples (0 to $5 \mathrm{~cm}$ depth) for determination of soil moisture, $\mathrm{pH}$ 
and $\mathrm{C} / \mathrm{N}$ were collected randomly with an auger at each site. They were taken monthly from April 1998 to May 1999. Soil samples were also collected before (Sept. B) and four days after (Sept. A) the prescribed fire in September 1998. Soil water content was determined by the gravimetric method. For soil $\mathrm{C} / \mathrm{N}$ and $\mathrm{pH}$ analysis, the samples were air-dried and screened with a $2 \mathrm{~mm}$ sieve. Total $\mathrm{N}$ content was determined by Kjeldahl digestion and organic $\mathrm{C}$ by the Walkley-Black procedure. Values of $\mathrm{pH}$ were measured in water and $\mathrm{KCl} 1 \mathrm{~N}(1: 2.5$, soil:water ratio). Six extra soil samples ( 0 to $5 \mathrm{~cm}$ depth) collected in March 1999 were used for determinations of soil texture, particle and bulk density, total porosity and field capacity and analyses were performed at Embrapa-Centro de Pesquisa Agropecuária dos Cerrados, Planaltina, DF, Brazil.

Rates of net $\mathrm{N}$ mineralization were measured over a period of one year (April 1998 to May 1999). PVC cores (10 $\mathrm{cm}$ long x $5 \mathrm{~cm}$ diameter), perforated by four holes at $5 \mathrm{~cm}$, were driven into the soil to the $5 \mathrm{~cm}$ mark and capped on top as described by Adams \& Attiwill (1986). The caps avoid leaching of inorganic-N in soil profile and runoff in the studied sites is negligible. Ten PVC cores were arranged in three parallel lines $15 \mathrm{~m}$ apart from each other with cores positioned every $5 \mathrm{~m}$. Soil samples from all ten PVC cores located at each site were collected at the beginning, one and two months after the beginning of the incubation. At the beginning of incubation period, soil samples were collected near the core and for one month period, samples were collected from the core with minimal disturbance (i.e. almost all soil in the core was left for the two month period). In this method, overlapping sampling was obtained and allowed the estimation of balances between net mineralization and net immobilization. This method best incorporates temperature and moisture variations into net $\mathrm{N}$ mineralization and net nitrification measurements (Knoepp \& Swank, 1995). The field-moist soil samples were extracted with $\mathrm{KCl} 1 \mathrm{~N}$ for 1 hour and the inorganic- $\mathrm{N}$ concentrations were determined by colorimetry. Ammoniacal nitrogen $\left(\mathrm{NH}_{4}-\mathrm{N}\right)$ was determined by the Nessler colorimetric method (soil analysis kit). Nitric nitrogen $\left(\mathrm{NO}_{3}-\mathrm{N}\right)$ was determined by a direct spectrophotometric analysis (UV-absorption) (Mulvaney, 1996), and in order to remove interferences by organic matter the difference in absorbance between 254 and $280 \mathrm{~nm}$ was used (Meier, 1991). All results were expressed on a $105^{\circ} \mathrm{C}$ oven-dry weight basis (DW). The inorganic-N available at the 0 to $5 \mathrm{~cm}$ soil depth corresponded to the concentration of inorganic-N measured at the beginning of each in- cubation period. Net $\mathrm{N}$ mineralization and net nitrification were defined and calculated as the change in $\mathrm{NO}_{3}-\mathrm{N}+\mathrm{NH}_{4}-\mathrm{N}$ and $\mathrm{NO}_{3}-\mathrm{N}$, respectively, during each incubation period.

The annual rates of net $\mathrm{N}$ mineralization and nitrification (in $\mathrm{kg} \mathrm{ha}^{-1}$ per year) were calculated using the sum of month values obtained (considering both mineralization and immobilization) and soil bulk density.

Soil microbial biomass $\mathrm{C}$ was determined by the chloroform fumigation-incubation method proposed by Jenkinson \& Powlson (1976). Soil microbial biomass was estimated from October 1998 to April 2000. Due to the heterogeneity of the native areas, a composite sample of the 10 soil samples (near the ten PVC cores) collected for available inorganic- $\mathrm{N}$ at the 0 to $5 \mathrm{~cm}$ soil depth was used to determine soil microbial biomass. Composite samples were used because the assessment of the variability of soil microbial biomass would demand a very intensive sampling effort and the processing of a large number of samples. Four replications from monthly composite samples were incubated in air tight flasks with water content adjusted to field capacity. Carbon dioxide $\left(\mathrm{CO}_{2}\right)$ evolved was trapped in a $0.3 \mathrm{~N} \mathrm{KOH}$ solution and quantified by titration using $0.1 \mathrm{~N} \mathrm{HCl}$ and phenolphthalein as indicator.

The normal distribution of the data was determined using Kolmogorov-Smirnoff test. The nonparametric test of Mann-Whitney and Kruskal-Wallis (Sokal \& Rohlf, 1997) were used to test differences between season or sites and months, respectively. The analyses were determined using the procedure of SYSTAT, version 7.0 for Windows (SPSS Inc., 1997). Differences at the 0.05 level were reported as significant.

\section{Results and Discussion}

The $\mathrm{C} / \mathrm{N}$ ratio of the soils studied (22/1) is larger than the value (20/1) that has been proposed as the threshold between net mineralization and net immobilization (Killham, 1994) (Table 1). The soil $\mathrm{C} / \mathrm{N}$ ratio did not differ significantly between the rainy and the dry season $(\mathrm{P}<0.05)$ in both sites. The studied soils presented low bulk density, high permeability and good aeration as the cerrado soils described by Luchiari Júnior et al. (1987). In general, the physical properties of these soils ( 0 to $5 \mathrm{~cm}$ depth) were not affected by the fire regime applied in the studied site (Table 1). Raison (1979) showed that severe fires affected infiltration, water-holding capacity and the 
thermal regime of the soil in other ecosystems. In the Cerrado, however, the residence time of the fire front is short and changes in soil temperature are small because the fuel that accumulates is fine grass (Miranda et al., 1993).

Annual rainfall was greater in $1997(1,480 \mathrm{~mm})$ than in 1998 (1,333 $\mathrm{mm})$ and in $1999(1,207 \mathrm{~mm})$. Although in 1998 it rained more than in 1999, the dry season was longer than in 1999, falling less than $13 \mathrm{~mm}$ between May and September 1998. Two small rain events $(<1 \mathrm{~mm})$ occurred into the following week after the prescribed fire in September 1998. The first heavy rain event $(26.2 \mathrm{~mm})$ was reported 18 days after fire. The soil moisture content was significantly higher in the rainy season (October to April) in both sites $(\mathrm{P}<0.05)$ (Table 1). However, taking into account the whole period sampled, the unburned site had higher soil water content at the 0 to $5 \mathrm{~cm}$ depth than the burned site. Bustamante et al. (1998) observed lower soil water content in a burned cerrado site than in the unburned site until 15 months after the fire. The decrease of surface soil moisture can be due to the replacement of woody plants by grasses, which increases the use of water on the surface layers (Carreira et al., 1994).

In the unburned site, no significant differences in the $\mathrm{pH}$ values ( $\mathrm{pH}$ in water) were found between the rainy and dry season (Table 1 ). However, the mean $\mathrm{pH}$ value ( 0 to $5 \mathrm{~cm}$ depth) for the rainy period after the fourth prescribed fire was significantly higher compared to the dry season (May to September) before fire. This was probably due to the de- posit of ash on the soil surface at the burned site and its incorporation into the soils (Kauffman et al., 1992).

During the rainy season, the organic $\mathrm{C}$ at the 0 to $5 \mathrm{~cm}$ depth was significantly higher in the unburned site $(\mathrm{P}<0.05)$ (Table 1$)$. No significant difference was found in soil total $\mathrm{N}$ (0 to $5 \mathrm{~cm}$ depth) between the rainy and the dry season in both sites. The mean concentration of total $\mathrm{N}$ was $0.15 \%$ for both sites.

Four days after fire (September 1998) a significant increase of inorganic- $\mathrm{N}$ due to an increase in $\mathrm{NH}_{4}-\mathrm{N}$ concentration was measured at the 0 to $5 \mathrm{~cm}$ soil layer $(\mathrm{P}<0.05)$ (Figure 1). However, in the following months after the fire, $\mathrm{NH}_{4}-\mathrm{N}$ concentration decreased in comparison to prefire levels. The $\mathrm{NH}_{4}-\mathrm{N}$ concentration ranged between 3 and $34 \mathrm{mg} \mathrm{kg}^{-1}$ in the burned site and between 3 and $22 \mathrm{mg} \mathrm{kg}^{-1}$ in the unburned site. During the dry period (May to September), the mean concentration of $\mathrm{NH}_{4}-\mathrm{N}$ at the 0 to $5 \mathrm{~cm}$ soil layer was $18.4 \mathrm{mg} \mathrm{kg}^{-1}$ for the burned site and $19.4 \mathrm{mg} \mathrm{kg}^{-1}$ for the unburned site while in the rainy season it was $6.7 \mathrm{mg} \mathrm{kg}^{-1}$ for both sites. The $\mathrm{NO}_{3}-\mathrm{N}$ concentration showed no seasonal variations in either of the sites, ranging from 1.5 to $2.8 \mathrm{mg} \mathrm{kg}^{-1}$ (Figure 1). This indicated that inorganic-N levels were higher during the dry season due largely to accumulation of $\mathrm{NH}_{4}-\mathrm{N}$ in the soil.

Rates of net $\mathrm{N}$ mineralization varied along the year and spatial variability was high within the studied sites, probably as a result of different deposition

Table 1. Soil physical and chemical characteristics of the cerrado soils studied (0 to $5 \mathrm{~cm}$ depth).

\begin{tabular}{|c|c|c|c|c|}
\hline Soil characteristics & \multicolumn{2}{|c|}{ Unburned site } & \multicolumn{2}{|c|}{ Burned site } \\
\hline Sand (\%) & \multicolumn{2}{|c|}{15} & \multicolumn{2}{|c|}{21} \\
\hline Silt (\%) & \multicolumn{2}{|c|}{11} & \multicolumn{2}{|c|}{13} \\
\hline Clay $(\%)$ & \multicolumn{2}{|c|}{74} & \multicolumn{2}{|c|}{66} \\
\hline Bulk density $\left(\mathrm{g} \mathrm{cm}^{-3}\right)^{(1)}$ & \multicolumn{2}{|c|}{$0.64(0.04)$} & \multicolumn{2}{|c|}{$0.67(0.05)$} \\
\hline Total porosity $(\%)^{(1)}$ & \multicolumn{2}{|c|}{$76.0(1.41)$} & \multicolumn{2}{|c|}{$75.6(2.07)$} \\
\hline & Rainy season ${ }^{(2)}$ & Dry season $^{(3)}$ & Rainy season $^{(2)}$ & Dry season ${ }^{(3)}$ \\
\hline $\mathrm{pH}$ in water & $4.7(0.23)$ & $4.5(0.15)$ & $5.0(0.07)^{*}$ & $4.7(0.05)^{*}$ \\
\hline $\mathrm{pH}$ in $\mathrm{KCl}$ & $3.9(0.10) *$ & $3.7(0.13) *$ & $4.1(0.07)$ & $4.1(0.17)$ \\
\hline Moisture content (\%) & $45.4(5.36) *$ & $28.8(2.78)^{*}$ & $39.0(6.16)^{*}$ & $24.7(3.65)^{*}$ \\
\hline Organic carbon $(\%)$ & $3.6(0.36) *$ & $3.3(0.47) *$ & $3.0(0.24)$ & $3.0(0.19)$ \\
\hline Total nitrogen (\%) & $0.16(0.08)$ & $0.14(0.02)$ & $0.15(0.02)$ & $0.15(0.01)$ \\
\hline Soil C/N & $21.8(2.07)$ & $23.1(1.11)$ & $22.2(3.48)$ & $20.3(1.41)$ \\
\hline
\end{tabular}

${ }^{(1)}$ Mean $\left(\mathrm{n}=6\right.$; 1SD) values. ${ }^{(2)}$ Mean $(\mathrm{n}=21 ; 1 \mathrm{SD})$ values from October 98 to April 99. ${ }^{(3)}$ Mean $(\mathrm{n}=18 ; 1 \mathrm{SD})$ values from May 98 to September 98. ${ }^{*}$ Significant difference between season in the same site by Mann-Whitney test $(\mathrm{P}<0.05)$. 
of organic matter and the nonuniformity of burnings. Net $\mathrm{N}$ mineralization might be directly related to the total content of $\mathrm{N}$ in the soil, to organic matter quality, to seasonal variations of organic substrates associated with litter production, and to environmental conditions (Hossain et al., 1995). Generally, net $\mathrm{N}$ mineralization occurred during the first 30 days of the in situ incubations (Figure 2). In contrast, the rates calculated after two months of incubation were frequently negative - that is, there was net $\mathrm{N}$ immobilization. The in situ method is sensitive to fluctuations in environmental conditions that may affect the rates of mineralization as the period of incubation increases (Adams et al., 1989).

In both sites, variations found in net $\mathrm{N}$ mineralization rates were due more to availability of $\mathrm{NH}_{4}-\mathrm{N}$ in the soil rather than $\mathrm{NO}_{3}-\mathrm{N}$. Accumulation of $\mathrm{NO}_{3}-\mathrm{N}$ occurred in short periods during the rainy season (Figures 1 and 3). During the dry period (May to September) mineralization/imobilization processes were variable. After strong net $\mathrm{N}$ immobilization in September,
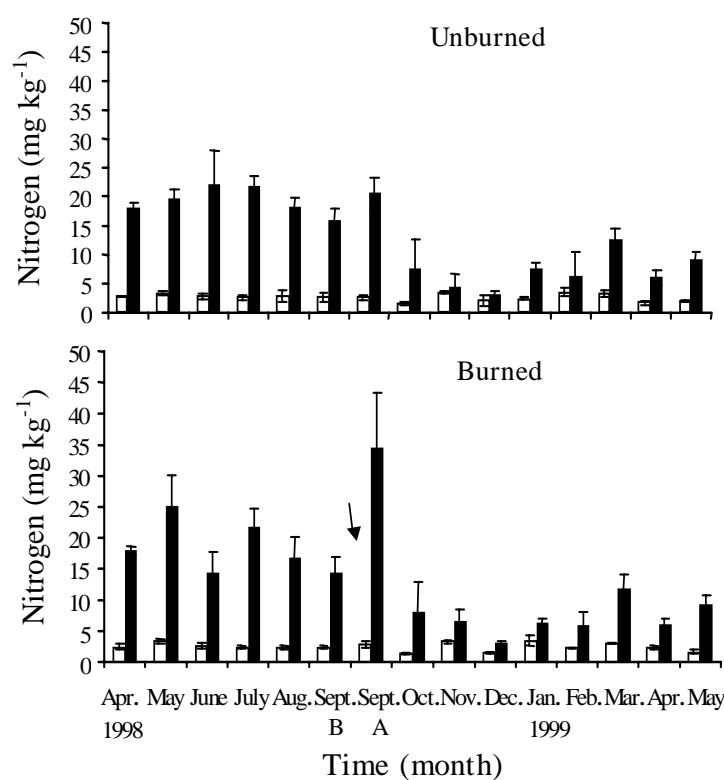

Figure 1. Mean concentrations ( $\mathrm{n}=10 ; 1 \mathrm{SD})$ of available inorganic-N $\left(\mathrm{NO}_{3}^{-}-\mathrm{N}: \square\right.$ and $\left.\mathrm{NH}_{4}^{-}-\mathrm{N}: \boldsymbol{\square}\right)$ at the 0 to $5 \mathrm{~cm}$ soil depth of the unburned and burned cerrado stricto sensu sites. The arrow indicates the prescribed fire and samples were taken before (Sept. B) and four days after (Sept. A) the burning. mainly in the burned site, a period of mineralization was reported during the rainy season, when maximum values of net $\mathrm{N}$ mineralization were found. In November, the rates of net $\mathrm{N}$ mineralization began to increase, reaching $12.4 \mathrm{mg} \mathrm{kg}^{-1}$ per 30 days in December 1998 in the unburned site. In the burned site, the maximum value of net $\mathrm{N}$ mineralization was $10.2 \mathrm{mg} \mathrm{kg}^{-1}$ per 30 days in February 1999 (Figure 2). In general, the net $\mathrm{N}$ mineralization rates observed in this study were similar to those determined for other seasonal ecosystems (Adams \& Attiwill, 1986; Carreira et al., 1994) but were lower than the rates found for tropical forests (Vitousek \& Matson, 1988; Verchot et al., 1999). Singh et al. (1989) also observed, in savannas of Central India, the highest rates during the rainy season and lowest rates in the dry period, indicating that soil moisture was the control factor of $\mathrm{N}$ mineralization in those ecosystems. Both sites presented the same pattern for mineralization/ immobilization, but the amount of inorganic- $\mathrm{N}$ cycled annually at the unburned site was $14.7 \mathrm{~kg} \mathrm{ha}^{-1}$ per

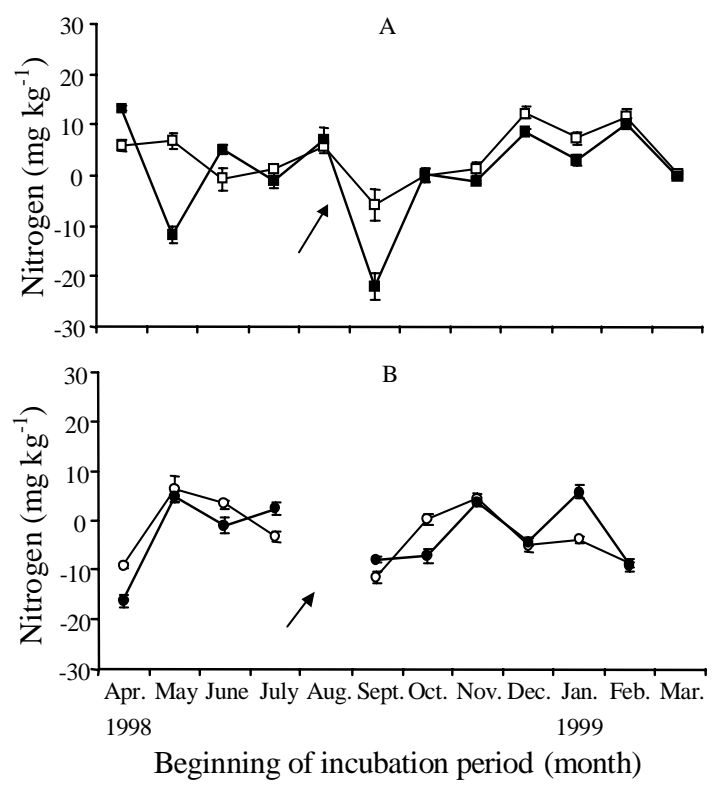

Figure 2. Net $\mathrm{N}$ mineralization rates for 0 to $5 \mathrm{~cm}$ soil depth, determined from in situ soil samples after 30 days of incubation ( $\mathrm{n}=10$; SE) (A) in the unburned $(\square)$ and burned ( $)$ sites, and after 60 days of incubation $(n=10$; SE) (B) in the unburned (O) and burned $(\bullet)$ sites between April 1998 and March 1999. The arrow indicates the prescribed fire.

Pesq. agropec. bras., Brasília, v. 38, n. 8, p. 955-962, ago. 2003 
year while at the burned site it was only $3.8 \mathrm{~kg} \mathrm{ha}^{-1}$ per year, one year after the burning.

In 1998, the unburned site showed a reduction of approximately $24 \%$ in soil microbial biomass $C$ from October to December while in the burned site (after the fire in September) an increase of 3.4 times in soil microbial biomass $\mathrm{C}$ was observed from October to November (maximum value of $850 \mathrm{mg} \mathrm{kg}^{-1}$ in November) with a subsequent decrease of $55.2 \%$ from November to December (Figure 4). In December 1998, both sites presented values of soil microbial biomass $\mathrm{C}$ of $350 \mathrm{mg} \mathrm{kg}^{-1}$. Concomitantly to the decrease in soil microbial biomass, increases in $\mathrm{N}$ mineralization from December to February occurred in both sites suggesting a peak of microbial activity with the first rain events and consequent immobilization followed by a period of mineralization. A decrease of soil microbial biomass from October to December was also observed in 1999 (one year after the fire). In accordance with other studies (Rashid, 1987; Bauhus et al., 1993), soils from

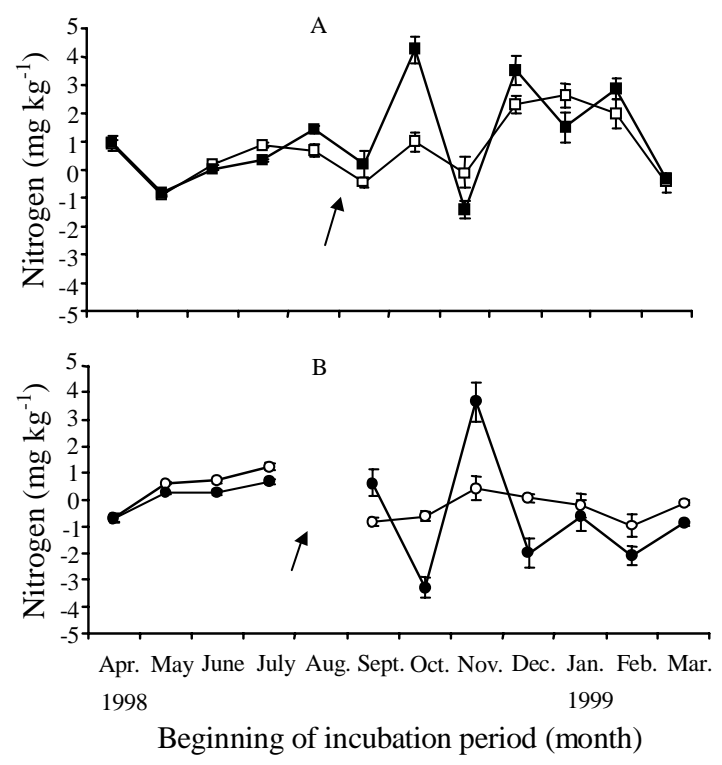

Figure 3. Net nitrification rates at the 0 to $5 \mathrm{~cm}$ soil depth, determined from in situ soil samples after 30 days of incubation ( $\mathrm{n}=10$; SE) (A) in the unburned $(\square)$ and burned ( $\square$ ) sites, and after 60 days of incubation $(n=10$; SE) (B) in the unburned ( $O$ ) and burned $(\bullet)$ sites between April 1998 and March 1999. The arrow indicates the prescribed fire. burned sites had initially higher soil microbial activities than unburned soils, but pools of readily available $\mathrm{C}$ were rapidly depleted. In Californian annual grassland, the period in which microbial $\mathrm{NH}_{4}{ }^{+}$utilization exceeded production lasted for a month after the first rain events, when the microbial $\mathrm{N}$ requirements were satisfied (Schimel et al., 1989). The soil microbial biomass dynamics in tropical forests and savannas allows accumulation and conservation of nutrients in biologically active forms during the dry period (high biomass, low turnover), when plant activities are low. At the beginning of the rainy period (low biomass, high turnover), nutrients are then released, being rapidly taken up by plants (Singh et al., 1989).

The low content in $\mathrm{NO}_{3}-\mathrm{N}$ of the soil studied is probably a consequence of the generally low availability of mineral $\mathrm{N}$, even though significant production of $\mathrm{NH}_{4}-\mathrm{N}$ occurred during the incubation periods. In the presence of plants, competition between plants and microorganisms for $\mathrm{NH}_{4}-\mathrm{N}$ is prob-

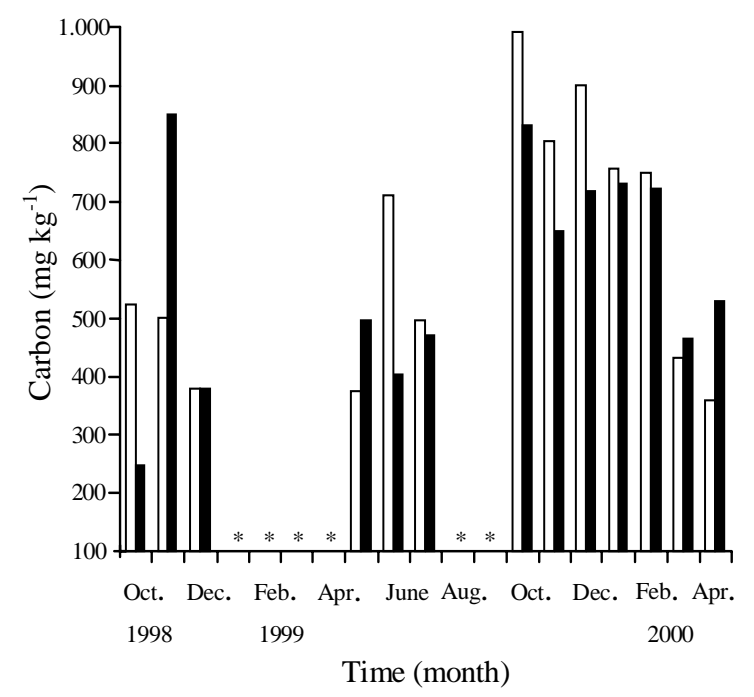

Figure 4. Soil microbial biomass $C$ for 0 to $5 \mathrm{~cm}$ depth, in the unburned $(\square)$ and burned ( $\square$ ) sites, estimated from October 1998 to April 2000, using four replications of monthly composite samples (same soil samples collected for available inorganic- $\mathrm{N}$ in the 0 to $5 \mathrm{~cm}$ soil interval). The asterisks mean missing data. 
ably intense. Hence, the population of nitrifying bacteria may be low and the incubation period was insufficient for significant expansions of these nitrifier populations. In soils of Mediterranean zone and in Australia, similar results were also explained by the low density of nitrifiers found in those soils, and no increase in nitrification after fire was detected (Prieto-Fernandez et al., 1993). Verchot et al. (1999) also showed low rates for potential nitrification for a Cerrado area. Possibly small increases in $\mathrm{NO}_{3}$ production could be rapidly taken up by plants and microorganisms, indicating $\mathrm{N}$ limitation in the ecosystem (Davidson et al., 1992).

Net $\mathrm{N}$ mineralization (Figure 2) and net nitrification rates (Figure 3) were highest during the rainy season but inorganic-N concentrations (Figure 1) decreased during the rainy season, indicating that plant uptake draws down inorganic-N stocks and consumes the $\mathrm{N}$ released from net $\mathrm{N}$ mineralization in a conservative $\mathrm{N}$ cycle.

\section{Conclusions}

1. Burned and unburned sites show the same pattern for mineralization/immobilization, however, the amount of inorganic-N cycled annually through mineralization process is lower in the burned site than in the unburned site.

2. Variations in the net $\mathrm{N}$ mineralization rates are largely due to availability of ammoniacal nitrogen.

3. Accumulation of nitric $\mathrm{N}$ occurs only in short periods during the rainy season.

4. The peak in microbial activities occurs at the beginning of the rains, with an initial period of net $\mathrm{N}$ immobilization followed by a period of net $\mathrm{N}$ mineralization.

\section{Acknowledgements}

To Reserva Ecológica do IBGE, for the precipitation data; to Dr. Heloísa Miranda (UnB) and the staff of Reserva Ecológica do IBGE, for their help with prescribed fires; to Maria Regina S. da Silva, for the laboratory assistance and Fabiano Nardoto and Ricardo Chiba, for their contributions in the field; to Prof. Geraldo Boaventura (UnB), for the laboratory facilities; to Dr. Eric Davidson (Woods
Hole Research Center), Dr. Iêda Mendes (EmbrapaCentro de Pesquisa Agropecuária dos Cerrados) and two anonymous reviewers, for helpful comments on this work; to Capes, for the fellowship of Gabriela Bielefeld Nardoto (Programa de Pós-graduação em Ecologia - UnB); to FAP-DF, for partial support of this work.

\section{References}

ADAMS, M. A.; ATTIWILL, P. M. Nutrient cycling and nitrogen mineralization in eucalypt forests of southeastern Australia - II: indices of nitrogen mineralization. Plant and Soil, Dordrecht, v. 92, p. 341-362, 1986.

ADAMS, M. A.; POLGLASE, P. J.; ATTIWILL, P. M.; WESTON, C. J. In situ studies of nitrogen mineralization and uptake in forest soils; some comments on methodology. Soil Biology \& Biochemistry, Oxford, v. 21, n. 3, p. 423-429, 1989.

BAUHUS, J.; KHANNA, P. K.; RAISON, R. J. The effect of fire on carbon and nitrogen mineralization and nitrification in an Australian forest soil. Soil Biology \& Biochemistry, Oxford, v. 31, p. 621-639, 1993.

BUSTAMANTE, M. M. C.; NARDOTO, F. B.; CASTRO, A. A. A.; GAROFALO, C. R.; NARDOTO, G. B.; SILVA, M. R. S. Effect of prescribed fires on the inorganic-N concentration in soil of cerrado areas and on the assimilation of inorganic-N by woody plants. In: INTERNATIONAL CONFERENCE ON FOREST FIRE RESEARCH, 3., 1998, Coimbra. Proceedings... Coimbra: University of Coimbra, 1998. v. 2, p. 1361-1379.

CARREIRA, J. A.; NIELL, F. X.; LAJTHA, K. Soil nitrogen availability and nitrification in Mediterranean shrublands of varying fire history and successional stage. Biogeochemistry, Dordrecht, v. 26, p. 189-209, 1994.

CRUTZEN, P.; ANDREAE, M. O. Biomass burning in the tropics: impact on atmospheric chemistry and biogeochemical cycles. Science, Washington, v. 250, p. 16691678, 1990.

DAVIDSON, E. A.; HART, S.; FIRESTONE, M. K. Internal cycling of nitrate in soils of a mature coniferous forest. Ecology, Washington, v. 73, p. 1148-1156, 1992.

EITEN, G. Vegetação do Cerrado. In: PINTO, M. N. (Org.). Cerrado: caracterização, ocupação e perspectivas. Brasília: Ed. Universidade de Brasília, 1994. p. 17-73. 
HOSSAIN, A. K.; RAISON, R. J.; KHANNA, P. K. Effects of fertilizer application and fire regime on soil microbial biomass carbon and nitrogen, and nitrogen mineralization in an Australian subalpine eucalypt forest. Biology and Fertility of Soils, New York, v. 19, p. 246-252, 1995.

JENKINSON, D. S.; POWLSON, D. S. The effects of biocidal treatments on metabolism in soil - V: a method for measuring soil biomass. Soil Biology \& Biochemistry, Oxford, v. 8, n. 3, p. 209-213, 1976.

KAUFFMAN, J. B.; TILL, K. M.; SHEA, R. W. Biogeochemistry of deforestation and biomass burning. In: DUNRETTE, D. A. (Ed.). The science of global change: the impact of human activities on the environment. Washington: American Chemical Society, 1992. p. 45-58. (American Chemical Society Symposium Series, 483).

KILLHAM, K. Soil ecology. Cambridge, England: University Press, 1994. 242 p.

KNOEPP, J. D.; SWANK, W. T. Comparison of available soil nitrogen assays in control and burned forested sites. Soil Science Society of American Journal, Madison, v. 59, p. 1750-1754, 1995.

LUCHIARI JÚNIOR, A.; RESENDE, M.; RITCHEY, K. D.; FREITAS JUNIOR, E. de; SOUZA, P. I. M. de. Manejo do solo e aproveitamento de água. In: GOEDERT, W. J. (Ed.). Solos dos cerrados: tecnologias de estratégias de manejo. Planaltina, DF: Embrapa-CPAC, 1987. p. 285322.

MEIER, M. Nitratbestimmung in Boden-Proben (N-minMethode). LaborPraxis, Würzburg, p. 244-247, 1991.

MIRANDA, A. C.; MIRANDA, H. S.; DIAS, I. F. O.; DIAS, B. F. Soil and air temperatures during prescribed cerrado fires in Central Brazil. Journal of Tropical Ecology, New York, v. 9, p. 313-320, 1993.

MIRANDA, H. S.; SILVA, E. P. R. e; MIRANDA, A. C. Comportamento do fogo em queimadas de campo sujo. In: MIRANDA, H. S.; SAITO, C. H.; DIAS, B. F. S. (Ed.) Impactos de queimadas em áreas de cerrado e restinga. Brasília: UnB, 1996. p. 1-10.

MULVANEY, R. L. Nitrogen inorganic forms. In: SPARKS, D. L. (Ed.). Methods of soil analyses. Madison: Soil Science Society of America, 1996. pt. 3, p. 1123 1184.

POTH, M.; ANDERSON, I. C.; MIRANDA, H. S.; MIRANDA, A. C.; RIGGAN, P. J. The magnitude and persistence of soil $\mathrm{NO}, \mathrm{N}_{2} \mathrm{O}, \mathrm{CH}_{4}$ and $\mathrm{CO}_{2}$ fluxes from burned tropical savanna in Brazil. Global Biogeochemical Cycles, Washington, v. 9, p. 503-513, 1995.

PRIETO-FERNANDEZ, A.; VILLAR, M. C.; CARBALLAS, M.; CARBALLAS, T. Short-term effects in a wildfire on the nitrogen status and its mineralization kinetics in an Atlantic forest soil. Soil Biology \& Biochemistry, Oxford, v. 25, n. 12, p. 1657-1664, 1993.

RAISON, R. J. Modification of the soil environment by vegetation fires, with particular reference to nitrogen transformations: a review. Plant and Soil, Dordrecht, v. 51, p. 73-108, 1979.

RASHID, G. H. Effects of fire on soil carbon and nitrogen in a Mediterranean forest of Algeria. Plant and Soil, Dordrecht, v. 103, p. 89-93, 1987.

SALGADO-LABOURIAU, M. L.; VICENTINI, K. R. F. Fire in the Cerrado 32,000 years ago. Current Research in the Pleistocene, Corvallis, v. 2, p. 85-87, 1994.

SATO, M. N.; GARDA, A. A.; MIRANDA, H. S. Effects of fire on the mortality of woody vegetation in Central Brazil. In: INTERNATIONAL CONFERENCE ON FOREST FIRE RESEARCH, 3., 1998, Coimbra. Proceedings... Coimbra: University of Coimbra, 1998. v. 2, p. $1777-1784$.

SCHIMEL, J. P.; JACKSON, L. E.; FIRESTONE, M. K. Spatial and temporal effects on plant microbial competition for inorganic nitrogen in a California annual grassland. Soil Biology \& Biochemistry, Oxford, v. 21, n. 8, p. 1059-1066, 1989.

SINGH, J. S.; RAGHBANSHI, A. S.; SINGH, R. S.; SRIVASTAVA, S. C. Microbial biomass acts as a source of plant nutrients in dry tropical forest and savanna. Nature, London, v. 388, p. 499-500, 1989.

SOKAL, R. R.; ROHLF, F. J. Biometry: the principles and practice of statistics in biological research. $3^{\text {rd }}$ ed. New York: W. H. Freeman, 1997. 887 p.

SPSS INC. (Chicago, United States). SYSTAT: version 7.0 for Windows. Chicago, 1997. 1 CD-ROM.

VERCHOT, L. V.; DAVIDSON, E. A.; CATTÂNIO, J. H.; ACKERMAN, I. L.; ERICSON, H. E.; KELLER, M. Land use change and biogeochemical controls of nitrogen oxide emissions from soils in eastern Amazonia. Global Biogeochemical Cycles, Washington, v. 13, n. 1, p. 31-46, 1999.

VITOUSEK, P. M.; MATSON, P. M. Nitrogen transformations in a range of tropical forest soils. Soil Biology $\&$ Biochemistry, Oxford, v. 20, p. 361-367, 1988. 